\title{
PENYIMPANGAN DAN PELANGGARAN PEMANFAATAN RUANG TERHADAP RENCANA TATA RUANG WILAYAH YANG TELAH DITETAPKAN PEMERINTAH DAERAH (STUDI KASUS DI BEBERAPA KABUPATEN/KOTA DI PROPINSI JAWA BARAT)
}

\author{
Oleh \\ Meta Indah Budhianti*)
}

\section{Abstrak}

Mewujudkan keterpaduan antara pelaksanaan rencana tata ruang dengan tidak mengabaikan kepentingan perorangan, berarti mencegah perbenturan kepentingan yang merugikan kegiatan pembangunan antar sektor, daerah dan masyarakat dalam penggunaan sumber daya manusia dan sumber daya buatan melalui proses koordinasi, integrasi dan sinkroniksasi perencanaan tata ruang, pemanfaatan ruang dan pengendalian pemanfaatan ruang. Penggantian yang layak diberikan kepada orang yang dirugikan selaku pemegang hak atas tanah, hak pengelolaan sumber daya alam seperti hutan, tambang, bahan galian, ikan dan atau ruang yang dapat membuktikan bahwa secara langsung dirugikan sebagai akibat pelaksanaan kegiatan pembangunan sesuai dengan rencana tata ruang dan oleh perubahan nilai ruang sebagai akibat penataan ruang. Sebagai penjawaban dari kebijaksanaan pembangunan perlu disusun rencana tata ruang wilayah di tiap Propinsi dan Kabupaten/Kota ternyata tidak semua Kabupaten/Kota menyusun dengan segera Rencana Tata Ruang Wilayah untuk wilayahnya. Bagi pemerintah daerah yang telah mempunyai Rencana Tata Ruang Wilayah ternyata masih banyak pelanggaran dan penyimpangan yang dilakukan oleh Pemerintah Daerah sendiri. Kurangnya partisipasi masyarakat dan kurangnya kesadaran dari masyarakat tentang pentingnya rencana tata ruang wilayah. Perubahan fungsi lingkungan untuk digunakan dan dikelola termasuk peruntukkan taman dan pantai harus tetap memperhatikan kebijakan sektor maupun kebijakan pembangunan yang berorientasi pada kelestarian fungsi lingkungan termasuk pula keserasian pada masyarakat sebagai pemegang kedaulatan publik. Dalam penelitian ini metode penelitian yang digunakan adalah normatif dengan menggunakan data sekunder dan data primer dan analisis datanya secara kualitatif sebagai penutup dari penelitian, peneliti menyarankan sebaiknya untuk mencegah dan/atau mengurangi pelanggaran terhadap RTRW yang telah ditetapkan PEMDA hendaknya konsekwen dalam penerapan RTRW dan terhadap pelaku pelanggaran penataan ruang dikenakan sanksi yang tegas.

\section{Kata Kunci : Rencana Tata Ruang Wilayah}

\section{A.PENDAHULUAN}

Ruang wilayah negara sebagai sumber daya alam terdiri dari berbagai ruang wilayah sebagai suatu sub sistem. Masing-masing subsistem meliputi aspek politik, ekonomi, sosial budaya, pertahanan keamanan dan kelembagaan dengan corak ragam dan daya dukung yang berbeda satu dengan yang lainnya. Seluruh wilayah negara Indonesia terdiri dari wilayah Nasional, wilayah Propinsi, dan wilayah Kabupaten/Kota, yang masing-

*) Penulis adalah Dosen Fakultas Hukum

Universitas Trisakti Jakarta 
masing merupakan subsistem ruang menurut batasan administrasi. Di dalam subsistem tersebut terdapat sumber daya manuasia dengan berbagai macam kegiatan pemanfaatan sumber daya alam, sumber daya buatan dan tingkat pemanfaatan ruang yang berbeda-beda, yang apabila tidak ditata secara baik dapat mendorong ke arah adanya ketidakseimbangan pembangunan antar wilayah serta ketidaklestarian lingkungan hidup.

Seiring dengan maksud tersebut, maka pelaksanaan pembangunan, baik di tingkat Pusat maupun di tingkat Daerah, harus sesuai dengan rencana tata ruang yang telah ditetapkan. Dengan demikian, pemanfaatan ruang tidak bertentangan dengan rencana tata ruang. Penataan ruang sebagai proses perencanaan tata ruang, pemanfaatan ruang dan pengendalian pemanfaatan ruang merupakan satu kesatuan sistem yang tidak terpisahkan satu dengan yang lainnya.

Mewujudkan keterpaduan antara pelaksanaan rencana tata ruang dengan tidak mengabaikan kepentingan perorangan, berarti mencegah perbenturan kepentingan yang merugikan kegiatan pembangunan antar sektor, daerah dan masyarakat dalam penggunaan sumber daya manusia dan sumber daya buatan melalui proses koordinasi, integrasi dan sinkroniksasi perencanaan tata ruang, pemanfaatan ruang dan pengendalian pemanfaatan ruang

Penggantian yang layak diberikan kepada orang yang dirugikan selaku pemegang hak atas tanah, hak pengelolaan sumber daya alam seperti hutan, tambang, bahan galian, ikan dan atau ruang yang dapat membuktikan bahwa secara langsung dirugikan sebagai akibat pelaksanaan kegiatan pembangunan sesuai dengan rencana tata ruang dan oleh perubahan nilai ruang sebagai akibat penataan ruang. Sebagai penjawaban dari kebijaksanaan pembangunan perlu disusun rencana tata ruang wilayah di tiap Propinsi dan Kabupaten/Kota ternyata tidak semua Kabupaten/Kota menyusun dengan segera Rencana Tata Ruang Wilayah untuk wilayahnya. Bagi pemerintah daerah yang telah mempunyai Rencana Tata Ruang Wilayah ternyata masih banyak pelanggaran dan penyimpangan yang dilakukan oleh Pemerintah Daerah sendiri. Kurangnya partisipasi masyarakat dan kurangnya kesadaran dari masyarakat tentang pentingnya rencana tata ruang wilayah.

Perubahan fungsi lingkungan untuk digunakan dan dikelola termasuk peruntukkan taman dan pantai harus tetap memperhatikan kebijakan sektor maupun kebijakan pembangunan yang berorientasi pada kelestarian fungsi lingkungan termasuk pula keserasian pada masyarakat sebagai pemegang kedaulatan publik. Beberapa pelanggaran terhadap Rencana Tata Ruang inilah yang menjadi pokok pembahasan dalam penelitian ini.

Dari uraian di atas, maka dapat dirumuskan masalah sebagai berikut :

1. Apakah Rencana Tata Ruang Wilayah yang telah ditetapkan sudah dilaksanakan sepenuhnya?

2. Apakah terdapat pelanggaran-pelanggaran yang dilakukan Pemerintah Daerah setempat terhadap Rencana Tata Ruang Wilayah yang telah ditetapkan dan berapa prosentase pelanggaran yang terjadi terhadap Rencana Tata Ruang Wilayah?

3. Adakah upaya PEMDA dalam rangka mengatasi pelanggaran terhadap Rencana Tata Ruang Wilayah Jawa Barat? 


\section{B. PEMBAHASAN}

\section{Kajian Teori Tentang Rencana Tata Guna Tanah/Ruang Dan Penatagunaan Tanah}

Pelaksanaan program pemanfaatan ruang merupakan aktivitas pembangunan, baik yang dilaksanakan oleh pemerintah maupun masyarakat untuk mewujudkan rencana tata ruang. Penyusunan program pemanfaatan ruang dilakukan berdasarkan indikasi program yang tertuang dalam rencana tata ruang dengan dilengkapi perkiraan pembiayaan.

Pemanfaatan ruang secara vertikal dan pemanfaatan ruang di dalam bumi dimaksudkan untuk meningkatkan kemampuan ruang dalam menampung kegiatan secara lebih intensif. Contoh pemanfaatan ruang secara vertikal misalnya berupa bangunan bertingkat, baik di atas tanah maupun di dalam bumi. Sementara itu, pemanfaatan ruang lainnya di dalam bumi, antara lain, untuk jaringan utilitas (jaringan transmisi listrik, jaringan telekomunikasi, jaringan pipa air bersih, dan jaringan gas, dan lain-lain) dan jaringan kereta api maupun jaringan jalan bawah tanah. Program pemanfaatan ruang dilaksanakan oleh seluruh pemangku kepentingan yang terkait.

Pemanfaatan Ruang berkaitan dengan Penatagunaan Tanah dan Sumber Daya Alam lainnya ditegaskan dalam Pasal 33 :

(1) Pemanfaatan ruang mengacu pada fungsi ruang yang ditetapkan dalam rencana tata ruang dilaksanakan dengan mengembangkan penatagunaan tanah, penatagunaan air, penatagunaan udara, dan penatagunaan sumber daya alam lain.

(2) Dalam rangka pengembangan penatagunaan sebagaimana dimaksud pada ayat (1) diselenggarakan kegiatan penyusunan dan penetapan neraca penatagunaan tanah, neraca penatagunaan sumber daya air, neraca penatagunaan udara, dan neraca penatagunaan sumber daya alam lain.

(3) Penatagunaan tanah pada ruang yang direncanakan untuk pembangunan prasarana dan sarana bagi kepentingan umum memberikan hak prioritas pertama bagi Pemerintah dan pemerintah daerah untuk menerima pengalihan hak atas tanah dari pemegang hak atas tanah.

(4) Dalam pemanfaatan ruang pada ruang yang berfungsi lindung, diberikan prioritas pertama bagi Pemerintah dan pemerintah daerah untuk menerima pengalihan hak atas tanah dari pemegang hak atas tanah jika yang bersangkutan akan melepaskan haknya.

(5) Ketentuan lebih lanjut mengenai penatagunaan tanah, penatagunaan air, penatagunaan udara, dan penatagunaan sumber daya alam lainnya sebagaimana dimaksud pada ayat (1) dan ayat (2) diatur dengan peraturan pemerintah.

\section{Pengendalian Pemanfaatan Ruang}

Pengendalian pemanfaatan ruang dilakukan melalui penetapan peraturan zonasi, perizinan, pemberian insentif dan disinsentif, serta pengenaan sanksi.

Sedangkan maksud dari Pengendalian Penataan Ruang ditegaskan dalam penjelasan Pasal 35, bahwa : Pengendalian pemanfaatan ruang dimaksudkan agar pemanfaatan ruang dilakukan sesuai dengan rencana tata ruang.

Peraturan tentang Zonasi ditegaskan dalam Pasal 36 sebagai berikut :

(1) Peraturan zonasi sebagaimana dimaksud dalam Pasal 35 disusun sebagai pedoman pengendalian pemanfaatan ruang.

(2) Peraturan zonasi disusun berdasarkan rencana rinci tata ruang untuk setiap zona pemanfaatan ruang.

(3) Peraturan zonasi ditetapkan dengan : 
a. Peraturan pemerintah untuk arahan peraturan zonasi sistem nasional;

b. Peraturan daerah provinsi untuk arahan peraturan zonasi sistem provinsi; dan

c. Peraturan daerah kabupaten/kota untuk peraturan zonasi.

Peraturan zonasi merupakan ketentuan yang mengatur pemanfaatan ruang dan unsur-unsur pengendalian yang disusun untuk setiap zona peruntukan sesuai dengan rencana rinci tata ruang. Peraturan zonasi berisi ketentuan yang harus, boleh, dan tidak boleh dilaksanakan pada zona pemanfaatan ruang yang dapat terdiri atas ketentuan tentang amplop ruang (koefisien dasar ruang hijau, koefisien dasar bangunan, koefisien lantai bangunan, dan garis sempadan bangunan), penyediaan sarana dan prasarana, serta ketentuan lain yang dibutuhkan untuk mewujudkan ruang yang aman, nyaman, produktif, dan berkelanjutan. Ketentuan lain yang dibutuhkan, antara lain, adalah ketentuan pemanfaatan ruang yang terkait dengan keselamatan penerbangan, pembangunan pemancar alat komunikasi, dan pembangunan jaringan listrik tegangan tinggi.

Ketentuan lebih lanjut mengenai pengendalian pemanfaatan ruang diatur dalam Pasal 37 sebagai berikut :

(1) Ketentuan perizinan sebagaimana dimaksud dalam Pasal 35 diatur oleh Pemerintah dan pemerintah daerah menurut kewenangan masing-masing sesuai dengan ketentuan peraturan perundang-undangan.

(2) Izin pemanfaatan ruang yang tidak sesuai dengan rencana tata ruang wilayah dibatalkan oleh Pemerintah dan pemerintah daerah menurut kewenangan masing-masing sesuai dengan ketentuan peraturan perundang-undangan.
(3) Izin pemanfaatan ruang yang dikeluarkan dan/atau diperoleh dengan tidak melalui prosedur yang benar, batal demi hukum.

(4) Izin pemanfaatan ruang yang diperoleh melalui prosedur yang benar tetapi kemudian terbukti tidak sesuai dengan rencana tata ruang wilayah, dibatalkan oleh Pemerintah dan pemerintah daerah sesuai dengan kewenangannya.

(5) Terhadap kerugian yang ditimbulkan akibat pembatalan izin sebagaimana dimaksud pada ayat (4), dapat dimintakan penggantian yang layak kepada instansi pemberi izin.

(6) Izin pemanfaatan ruang yang tidak sesuai lagi akibat adanya perubahan rencana tata ruang wilayah dapat dibatalkan oleh Pemerintah dan pemerintah daerah dengan memberikan ganti kerugian yang layak.

(7) Setiap pejabat pemerintah yang berwenang menerbitkan izin pemanfaatan ruang dilarang menerbitkan izin yang tidak sesuai dengan rencana tata ruang.

(8) Ketentuan lebih lanjut mengenai prosedur perolehan izin dan tata cara penggantian yang layak sebagaimana dimaksud pada ayat (4) dan ayat (5) diatur dengan peraturan pemerintah.

Yang dimaksud dengan perizinan adalah perizinan yang terkait dengan izin pemanfaatan ruang yang menurut ketentuan peraturan perundang-undangan harus dimiliki sebelum pelaksanaan pemanfaatan ruang. Izin dimaksud adalah izin lokasi/fungsi ruang, amplop ruang, dan kualitas ruang.

Ketentuan mengenai INSENTIF dan DISINSENTIF dimuat dalam Pasal 38 yang menyatakan :

(1) Dalam pelaksanaan pemanfaatan ruang agar pemanfaatan ruang sesuai dengan rencana tata ruang wilayah dapat diberikan insentif dan/atau 
disinsentif oleh Pemerintah dan pemerintah daerah.

(2) Insentif sebagaimana dimaksud dalam Pasal 35, yang merupakan perangkat atau upaya untuk memberikan imbalan terhadap pelaksanaan kegiatan yang sejalan dengan rencana tata ruang, berupa:

a. Keringanan pajak, pemberian kompensasi, subsidi silang, imbalan, sewa ruang, dan urun saham;

b. Pembangunan serta pengadaan infrastruktur;

c. Kemudahan prosedur perizinan; dan/atau

d. Pemberian penghargaan kepada masyarakat, swasta dan/atau pemerintah daerah.

(3) Disinsentif sebagaimana dimaksud dalam Pasal 35, yang merupakan perangkat untuk mencegah, membatasi pertumbuhan, atau mengurangi kegiatan yang tidak sejalan dengan rencana tata ruang berupa :

a. Pengenaan pajak yang tinggi yang disesuaikan dengan besarnya biaya yang dibutuhkan untuk mengatasi dampak yang ditimbulkan akibat pemanfaatan ruang; dan/atau

b. Pembatasan penyediaan infrastruktur, pengenaan kompensasi, dan penalti.

(4) Insentif dan disinsentif diberikan dengan tetap menghormati hak masyarakat.

(5) Insentif dan disinsentif dapat diberikan oleh :

a. Pemerintah kepada pemerintah daerah;

b. Pemerintah daerah kepada pemerintah daerah lainnya; dan

c. Pemerintah kepada masyarakat.

(6) Ketentuan lebih lanjut mengenai bentuk dan tata cara pemberian insentif dan disinsentif diatur dengan peraturan pemerintah.
Penerapan insentif atau disinsentif secara terpisah dilakukan untuk perizinan skala kecil/individual sesuai dengan peraturan zonasi, sedangkan penerapan insentif dan disinsentif secara bersamaan diberikan untuk perizinan skala besar/ kawasan karena dalam skala besar/ kawasan dimungkinkan adanya pemanfaatan ruang yang dikendalikan dan didorong pengembangannya secara bersamaan. Disinsentif berupa pengenaan pajak yang tinggi dapat dikenakan untuk pemanfaatan ruang yang tidak sesuai rencana tata ruang melalui penetapan nilai jual objek pajak (NJOP) dan nilai jual kena pajak (NJKP) sehingga pemanfaat ruang membayar pajak lebih tinggi. Insentif dapat diberikan antar pemerintah daerah yang saling berhubungan berupa subsidi silang dari daerah yang penyelenggaraan penataan ruangnya memberikan dampak kepada daerah yang dirugikan, atau antara pemerintah dan swasta dalam hal pemerintah memberikan preferensi kepada swasta sebagai imbalan dalam mendukung perwujudan rencana tata ruang.

Pengenaan sanksi sebagaimana dimaksud dalam Pasal 35 merupakan tindakan penertiban yang dilakukan terhadap pemanfaatan ruang yang tidak sesuai dengan rencana tata ruang dan peraturan zonasi (Pasal 39).

Pengendalian Pemanfaatan Ruang akan diatur dalam Peraturan Pemerintah ditegaskan dalam Pasal 40 adalah ketentuan lebih lanjut mengenai pengendalian pemanfaatan ruang diatur dengan peraturan pemerintah.

\section{Pengawasan Penataan Ruang}

Pelaksanaan Pengawasan Penataan Ruang ditegaskan dalam Pasal 55 :

(1) Untuk menjamin tercapainya tujuan penyelenggaraan penataan ruang sebagaimana dimaksud dalam Pasal 3, dilakukan pengawasan terhadap 
kinerja pengaturan, pembinaan, dan pelaksanaan penataan ruang.

(2) Pengawasan sebagaimana dimaksud pada ayat (1) terdiri atas tindakan pemantauan, evaluasi, dan pelaporan.

(3) Pengawasan sebagaimana dimaksud pada ayat (2) dilaksanakan oleh Pemerintah dan pemerintah daerah sesuai dengan kewenangannya.

(4) Pengawasan Pemerintah dan pemerintah daerah sebagaimana dimaksud pada ayat (3) dilakukan dengan melibatkan peran masyarakat.

(5) Peran masyarakat sebagaimana dimaksud pada ayat (4) dapat dilakukan dengan menyampaikan laporan dan/atau pengaduan kepada Pemerintah dan pemerintah daerah.

Pengawasan terhadap kinerja pengaturan, pembinaan, dan pelaksanaan penataan ruang dimaksudkan untuk menjamin terlaksananya peraturan perundang-undangan, terselenggaranya upaya pemberdayaan penataan ruang. Kegiatan pengawasan termasuk pula pengawasan melekat dalam unsur-unsur struktural pada setiap tingkatan wilayah. Tindakan pemantauan, evaluasi, dan pelaporan terhadap penyelenggaraan penataan ruang merupakan kegaitan mengamati dengan cermat, menilai tingkat pencapaian rencana secara objektif, dan memberikan informasi hasil evaluasi secara terbuka.

Tugas Gubernur dan Walikota/Bupati dalam rangka Pemantauan dan Evaluasi ditegaskan dalam Pasal 56 :

(1) Pemantauan dan evaluasi sebagaimana dimaksud dalam Pasal 55 ayat (2) dilakukan dengan mengamati dan memeriksa kesesuaian antara penyelenggaraan penataan ruang dengan ketentuan peraturan perundangundangan.

(2) Apabila hasil pemantauan dan evaluasi sebagaimana dimaksud pada ayat (1) terbukti terjadi penyimpangan administratif dalam penyelenggaraan penataan ruang, Menteri, Gubernur, dan Bupati/Walikota mengambil langkah penyelesaian sesuai dengan kewenangannya.

(3) Dalam hal Bupati/Walikota tidak melaksanakan langkah penyelesaian sebagaimana dimaksud pada ayat (2), Gubernur mengambil langkah penyelesaian yang tidak dilaksanakan Bupati/Walikota.

(4) Dalam hal Gubernur tidak melaksanakan langkah penyelesaian sebagaimana dimaksud pada ayat (2) dan ayat (3), Menteri mengambil langkah penyelesaian yang tidak dilaksanakan Gubernur.

Langkah penyelesaian merupakan tindakan nyata pejabat administrasi, antara lain, berupa tindakan administratif untuk menghentikan terjadinya penyimpangan. Jika ternyata ada penyimpangan, maka Pasal 57 menegaskan dalam hal penyimpangan dalam penyelenggaraan penataan ruang sebagaimana dimaksud dalam Pasal 56 ayat (2), pihak yang melakukan penyimpangan dapat dikenai sanksi sesuai dengan ketentuan peraturan perundang-undangan.

Dalam rangka pengawasan lebih lanjut ditegaskan Pasal 58 :

(1) Untuk menjamin tercapainya tujuan penyelenggaraan penataan ruang sebagaimana dimaksud dalam Pasal 3, dilakukan pula pengawasan terhadap kinerja fungsi dan manfaat penyelenggaraan penataan ruang dan kinerja pemenuhan standar pelayanan minimal bidang penataan ruang.

(2) Dalam rangka peningkatan kinerja fungsi, dan manfaat penyelenggaraan penataan ruang wilayah nasional disusun standar pelayanan penyelenggaraan penataan ruang untuk tingkat nasional.

(3) Standar pelayanan minimal bidang penataan ruang sebagaimana dimaksud pada ayat (1) meliputi aspek pelayanan dalam perencanaan tata 
ruang, pemanfaatan ruang, dan pengendalian pemanfaatan ruang.

(4) Standar pelayanan minimal sebagaimana dimaksud pada ayat (1) mencakup standar pelayanan minimal bidang penataan ruang provinsi dan standar pelayanan minimal bidang penataan ruang kabupaten/kota.

(5) Ketentuan lebih lanjut mengenai standar pelayanan minimal bidang penataan ruang sebagaimana dimaksud pada ayat (3) dan ayat (4) diatur dengan peraturan Menteri.

Standar pelayanan minimal merupakan hak dan kewajiban penerima dan pemberi layanan yang disusun sebagai alat Pemerintah dan pemerintah daerah untuk menjamin masyarakat memperoleh jenis dan mutu pelayanan dasar secara merata dalam rangka penyelenggaraan urusan wajib. Jenis pelayanan dalam perencanaan tata ruang wilayah provinsi/kabupaten/kota, antara lain, adalah pelibatan masyarakat dalam penyusunan rencana tata ruang wilayah provinsi/ kabupaten/kota, sedangkan mutu pelayanannya dinyatakan dengan frekuensi pelibatan masyarakat. Standar pelayanan minimal bidang penataan ruang provinsi/ kabupaten/kota ditetapkan Pemerintah sebagai alat untuk menjamin jenis dan mutu pelayanan dasar yang diberikan pemerintah provinsi/kabupaten/kota kepada masyarakat secara merata dalam rangka penyelenggaraan penataan ruang.

Tentang "Pedoman" dan Tata Cara Pengawasan ditegaskan Pasal 59 :

(1) Pengawasan terhadap penataan ruang pada setiap tingkat wilayah dilakukan dengan menggunakan pedoman bidang penataan ruang.

(2) Pengawasan sebagaimana dimaksud pada ayat (1) ditujukan pada pengaturan, pembinaan, dan pelaksanaan penataan ruang.

(3) Ketentuan lebih lanjut mengenai tata cara pengawasan terhadap pengaturan, pembinaan, dan pelaksanaan penataan ruang diatur dengan peraturan Menteri.

\section{Hak, Kewajiban dan Peran Masyarakat Dalam Penataan Ruang}

Hak-hak setiap orang yang berkaitan dengan Penataan Ruang, ditegaskan dalam Pasal 60 :

Dalam penataan ruang, setiap orang berhak untuk :

a. Mengetahui rencana tata ruang;

b. Menikmati pertambahan nilai ruang sebagai akibat penataan ruang;

c. Memperoleh penggantian yang layak atas kerugian yang timbul akibat pelaksanaan kegiatan pembangunan yang sesuai dengan rencana tata ruang;

d. Mengajukan keberatan kepada pejabat berwenang terhadap pembangunan yang tidak sesuai dengan rencana tata ruang di wilayahnya;

e. Mengajukan tuntutan pembatalan izin dan penghentian pembangunan yang tidak sesuai dengan rencana tata ruang kepada pejabat berwenang; dan

f. Mengajukan gugatan ganti kerugian kepada pemerintah dan/atau pemegang izin apabila kegiatan pembangunan yang tidak sesuai dengan rencana tata ruang menimbulkan kerugian.

Masyarakat dapat mengetahui rencana tata ruang melalui Lembaran Negara atau Lembaran Daerah, pengumuman, dan/atau penyebarluasan oleh pemerintah. Pengumuman atau penyebarluasan tersebut dapat diketahui masyarakat, antara lain, adalah pemasangan peta rencana tata ruang wilayah yang bersangkutan pada tempat umum, kantor kelurahan, dan/atau kantor yang secara fungsional menangani rencana tata ruang tersebut.

Pertambahan nilai ruang dapat dilihat dari sudut pandang ekonomi, sosial, budaya, dan kualitas lingkungan yang 
dapat berupa dampak langsung terhadap peningkatan ekonomi masyarakat, sosial, budaya, dan kualitas lingkungan. Yang dimaksud dengan penggantian yang layak adalah bahwa nilai atau besarnya penggantian tidak menurunkan tingkat kesejahteraan orang yang diberi penggantian sesuai dengan ketentuan peraturan perundang-undangan.

Kewajiban setiap orang dalam Pemanfaatan Ruang ditegaskan dalam Pasal 61:

a. Menaati rencana tata ruang yang telah ditetapkan;

b. Memanfaatkan ruang sesuai dengan izin pemanfaatan ruang dan pejabat yang berwenang;

c. Mematuhi ketentuan yang ditetapkan dalam persyaratan izin pemanfaatan ruang; dan

d. Memberikan akses terhadap kawasan yang oleh ketentuan peraturan perundang-undangan dinyatakan sebagai milik umum.

Menaati rencana tata ruang yang telah ditetapkan dimaksudkan sebagai kewajiban setiap orang untuk memiliki izin pemanfaatan ruang dari pejabat yang berwenang sebelum pelaksanaan pemanfaatan ruang. Memanfaatkan ruang sesuai dengan izin pemanfaatan ruang dimaksudkan sebagai kewajiban setiap orang untuk melaksanakan pemanfaatan ruang sesuai dengan fungsi ruang yang tercantum dalam izin pemanfaatan ruang. Mematuhi ketentuan yang ditetapkan dalam persyaratan izin pemanfaatan ruang dimaksudkan sebagai kewajiban setiap orang untuk memenuhi ketentuan amplop ruang dan kualitas ruang.

Pemberian akses dimaksudkan untuk menjamin agar masyarakat dapat mencapai kawasan yang dinyatakan dalam peraturan perundang-undangan sebagai milik umum. Kewajiban memberikan akses dilakukan apabila memenuhi syarat berikut :

a. Untuk kepentingan masyarakat umum; dan/atau b. Tidak ada akses lain menuju kawasan dimaksud.

Yang dimaksud dalam kawasan yang dinyatakan sebagai milik umum, antara lain, adalah sumber air dan pesisir pantai. Setiap orang yang melanggar ketentuan sebagaimana dimaksud dalam Pasal 61, dikenai sanksi administratif (Pasal 62). Sanksi administratif sebagaimana dimaksud dalam Pasal 62 dapat berupa (Pasal 63):

a. Peringatan tertulis;

b. Penghentian sementara kegiatan;

c. Penghentian sementara pelayanan umum;

d. Penutupan lokasi;

e. Pencabutan izin;

f. Pembatalan izin;

g. Pembongkaran bangunan;

h. Pemulihan fungsi ruang; dan/atau

i. Denda administratif.

Penghentian sementara pelayanan umum dimaksud berupa pemutusan sambungan listrik, saluran air bersih, saluran limbah, dan lain-lain yang menunjang suatu kegiatan pemanfaatan ruang yang tidak sesuai dengan rencana tata ruang. Pembongkaran dimaksud dapat dilakukan secara sukarela oleh yang bersangkutan atau dilakukan oleh instansi berwenang.

Ketentuan lebih lanjut mengenai kriteria dan tata cara pengenaan sanksi administratif sebagaimana dimaksud pada Pasal 63 diatur dengan peraturan pemerintah (Pasal 64).

Peran masyarakat dalam Penataan Ruang ditegaskan dalam Pasal 65.

(1) Penyelenggaraan penataan ruang dilakukan oleh pemerintah dengan melibatkan peran masyarakat.

(2) Peran masyarakat dalam penataan ruang sebagaimana dimaksud pada ayat (1) dilakukan, antara lain, melalui :

a. Partisipasi dalam penyusunan rencana tata ruang; 
b. Partisipasi dalam pemanfaatan ruang; dan

c. Partisipasi dalam pengendalian pemanfaatan ruang.

(3) Ketentuan lebih lanjut mengenai tata cara dan bentuk peran masyarakat dalam penataan ruang sebagaimana dimaksud pada ayat (1) diatur dengan peraturan pemerintah.

Peran masyarakat sebagai pelaksana pemanfaatan ruang, baik orang perseorangan maupun korporasi, antara lain mencakup kegiatan pemantaatan ruang yang sesuai dengan rencana tata ruang.

Gugatan Perdata yang dapat diajukan oleh masyarakat yang dirugikan ditegaskan Pasal 66.

(1) Masyarakat yang dirugikan akibat penyelenggaraan penataan ruang dapat mengajukan gugatan melalui pengadilan.

(2) Dalam hal masyarakat mengajukan gugatan sebagaimana dimaksud pada ayat (1), tergugat dapat membuktikan bahwa tidak terjadi penyimpangan dalam penyelenggaraan penataan ruang.

Kerugian akibat penyelenggaraan penataan ruang mencakup pula kerugian akibat tidak memperoleh informasi rencana tata ruang yang disebabkan oleh tidak tersedianya informasi tentang rencana tata ruang.

Mengenai PENYELESAIAN SENGKETA baik melalui Pengadilan atau di luar Pengadilan ditegaskan dalam Pasal 67.

(1) Penyelesaian sengketa penataan ruang pada tahap pertama diupayakan berdasarkan prinsip musyawarah untuk mufakat.

Dalam hal penyelesaian sengketa sebagaimana dimaksud pada ayat (1) tidak diperoleh kesepakatan, para pihak dapat menempuh upaya penyelesaian sengketa melalui pengadilan atau di luar pengadilan sesuai dengan ketentuan peraturan perundang-undangan.
Penyimpangan dari Rencana Tata Ruang Wilayah yang telah ditetapkan PEMDA Jawa Barat paling banyak terjadi di Kabupaten Bogor, Puncak dan Cianjur.

\section{Analisis Pelanggaran Rencana Tata Ruang Wilayah Kabupaten Bogor}

Dampak dari meningkatnya kegiatan di wilayah DKI Jakarta sebagai kota jasa sangat besar pengaruhnya terhadap perkembangan wilayah sekitarnya, termasuk Kabupaten Bogor. Hal ini ditunjukkan dengan meningkatnya ekspansi kawasan-kawasan perumahan, baik verskala besar, menengah, maupun skala kecil. Selain itu, letak Kabupaten Bogor, yang berbatasan langsung dengan Ibukota Indonesia tersebut serta ditunjang dengan aksesibilitas yang relatif baik, sangat diminati oleh para investor yang bergerak dalam bidang industria dan perumahan sehingga pertumbuhan wilayah Kabupaten Bogor sangat dipengaruhi oleh keberadaan kawasan industri dan perumahan.

Tinggi ekspansi perumahan dan industri tersebut membutuhkan penataan ruang yang baik untuk mengantisipasi perkembangan pembangunan fisik yang ditimbulkannya sehingga tercapai pemanfaatan ruang yang optimal, berkelanjutan demi kelangsungan hidup yang verkualitas. Upaya penataan ini dilakukan melalui berbagai kegiatan yang meliputi perencanaan tata ruang, pemanfaatan ruang dan pengendalian pemanfaatan ruang. Salah satu bentuk pengendalian pemanfaatan ruang tersebut adalah pemberian Ijin Lokasi maupun Ijin Peruntukkan Penggunaan Tanah. Kedua jenis perijinan tersebut pada hakikatnya berfungsi mengarahkan pemanfaatan ruang agar sejalan dengan Rencana Tata Ruang yang ada.

Pemerintah Daerah Kabupaten Bogor, secara prinsip memiliki 2 (dua) buah produk perijinan yang terkait dengan proses pengendalian pemanfaatan ruang, 
yaitu Ijin Lokasi dan Ijin Peruntukkan Penggunaan Tanah (IPPT). Pada dasarnya kedua produk perijinan tersebut sama apabila dilihat dari sisi fungsi sebagai salah satu perangkat pengendalian pemanfaatan ruang. Secara definisi, terdapat sedikit perbedaan, yaitu :

- Ijin Lokasi (Ilok) adalah ijin yang diberikan kepada perusahaan untuk memperoleh tanah yang diperlukan dalam rangka penanaman modal yang berlaku pula sebagai ijin pemindahan hak, dan untuk menggunakan tanah tersebut guna usaha penanaman modalnya. (Peraturan Menteri Negara Agraria/Kepala BPN No. 2 Tahun 1999). - Ijin Peruntukkan Penggunaan Tanah (IPPT) adalah ijin yang diberikan oleh Pemerintah Daerah kepada orang pribadi atau badan yang dimaksudkan untuk pembinaan, pengaturan, pengendalian dan pengawasan atas kegiatan pemanfaatan ruang guna melindungi kepentingan umum dan menjaga kelestarian lingkungan. (Perda Kabupaten Bogor No. 19 Tahun 2000).

Dari kedua definisi tersebut, dapat dibedakan bahwa subyek dalam ijin lokasi adalah setiap perusahaan yang vertujuan untuk memperoleh tanah. Artinya terdapat suatu proses pembebasan (mutasi) tanah, baik melalui proses transaksi jual beli maupun proses lainnya. Sedangkan dalam IPPT, subyeknya adalah orang pribadi atau badan yang melakukan kegiatan pemanfaatan ruang. Artinya apabila terdapat kegiatan pemanfaatan ruang, maka perlu diawali melalui suatu proses penerbitan IPPT. Dengan demikian IPPT sebenarnya lebih bersifat sebagai suatu Keterangan Pemanfaatan Ruang ("Advice Planning"), yang harus ditempuh sebelum dilakukannya suatu kegiatan pemanfaatan ruang.

Untuk menghindari duplikasi antara IPPT dan Ilok, Pemerintah Daerah Kabupaten Bogor, telah membedakan obyek pengenaan ijin berdasarkan status kepemilikan tanah. Apabila suatu rencana pemanfaatan ruang berkaitan dengan suatu proses pembebasan tanah, maka kegiatan tersebut harus diawali melalui proses ijin lokasi. Tetapi apabila tanah tersebut telah dimiliki (bersertifikat) dan tidak terjadi proses mutasi tanah, maka kegiatan tersebut diawali dengan proses IPPT.

Sejak diberikannya kewenangan proses dan penerbitan ijin lokasi kepada Pemerintah Daerah, sesuai amanat dari UU No. 2 Tahun 1999, Pemerintah Daerah Kabupaten Bogor telah melakukan langkah awal dengan menerbitkan beberapa aturan pendukung berupa Peraturan Daerah dan Surat Keputusan (SK) Bupati Bogor.

Ijin Lokasi di Kabupaten Bogor dikelola oleh Bagian Pemerintahan Umum sekretariat Daerah Kabupaten Bogor. Dinas Tata Ruang dan Lingkungan Hidup berperan sebagai anggota Tim Pemberi Pertimbangan. Tim ini memberikan penilaian pertimbangan sesuai dengan tugas pokok dan fungsi dinas/instansinya masing-masing. Diawali dengan peninjauan lapangan terhadap lokasi dimohon, setiap anggota tim mencatat kondisi fisik lapangan. Hasil pencatatan ini akan dibahas dalam tahap berikutnya, yaitu rapat pembahasan. Dalam tahap ini, setiap anggota tim berhak menyampaikan tanggapan terhadap permohonan ijin lokasi berdasarkan hasil peninjauan lapangan, sesuai dengan tugas pokok dan fungsinya. Apabila seluruh anggota tim memberikan tanggapan positif, maka permohonan ijin lokasi dapat diterima, dan sebaliknya.

Seperti telah dijelaskan pada bagian awal, bahwa selain ijin lokasi, jenis perijinan yang erat kaitannya dengan fungsi pengendalian pemanfaatan ruang di Kabupaten Bogor, adalah Ijin Peruntukkan Penggunaan Tanah (IPPT). IPPT ini dikelola oleh Dinas Tata Ruang dan Lingkungan Hidup, serta oleh Kecamatan 
(terbatas untuk pemukiman/rumah tinggal perorangan dan pertanian dengan luasan di bawah $3.000 \mathrm{~m}^{2}$ ). Pada prinsipnya perijinan ini merupakan "filter" awal bagi setiap kegiatan pemanfaatan ruang agar sesuai (mengacu) kepada rencana tata ruang yang ada. Substansi inti dari IPPT adalah informasi rencana pemanfaatan ruang paada lokasi yang akan dimanfaatkan (dibangun) sesuai dengan Rencana Tata Ruang yang berlaku. Selain informasi tersebut, substansi IPPT juga memuat beberapa ketentuan teknis sebagai berikut :

- Jenis-jenis bangunan yang diperbolehkan

- KDB/BCR yang diberikan

- Ketinggian bangunan maksimum yang diperkenankan

- GSB,GSP, serta GSS pada lokasi yang akan dimanfaatkan

- Serta informasi lain yang dianggap perlu

Menyadari tanggung jawab penerbitan IPPT yang begitu berat, Dinas Tata Ruang dan Lingkungan Hidup dalam proses penerbitannya menggunakan aplikasi teknologi "Global Positioning System" (GPS) dan alat bantú "Geografic Informations System" (GIS). Tujuan penggunaan keduanya adalah untuk menghindari "human errors", mencapai objektivitas seoptimal mungkin, serta sebagai langkah awal untuk membangun "database spasial". Dengan penggunaan GPS maka posisi suatu lokasi dapat dengan mudah diketahui, serta dengan bantuan "software" konversi koordinat, maka aplikasi posisi suatu lokasi dalam peta digital Rencana Tata Ruang yang ada, dengan cepat dan tepat dapat diketahui. Dengan mengambil beberapa titik koordinat di lapangan sebagai titik kontrol yang dikombinasikan dengan pencatatan rona awal lingkungan, maka usaha manipulasi posisi dapat semaksimal mungkin dihindari.
Berdasarkan UU No. 26 Tahun 2007, bahwa penataan ruang adalah proses perencanaan tata ruang, pemanfaatan ruang dan pengendalian pemanfaatan ruang, yang merupakan satu kesatuan yang terintegrasi. Dalam hal ini rencana tata ruang sebagai hasil perencanaan tata ruang harus dapat dijadikan pedoman dalam pemanfaatan ruang. Sedangkan perijinan sebagai salah satu bentuk pengendalian, pada hakikatnya berfungsi mengarahkan pemanfaatan ruang agar sesuai dengan rencana tata ruang. Dengan demikian keberhasilan penataan ruang bukan hanya ditentukan pada tahap perencanaan, tetapi juga ditentukan pada tahap implementasi rencana (pemanfaatan ruang).

Permasalahan yang sering terjadi dalam kenyataan (realitas) adalah tidak sesuainya pemanfaatan ruang dengan rencana tata ruang. Dengan kata lain sering terjadi penyimpangan (deviasi) pemanfaatan ruang yang tidak sesuai dengan rencana tata ruang. Hal ini menunjukkan terjadinya permasalahan dalam implementasi rencana tata ruang, baik dalam lingkup pemanfaatan dan/ atau pengendalian pemanfaatan ruang. Fakta-fakta menunjukkan telah terjadi deviasi rencana tata ruang di Kabupaten Bogor begitupun dengan Provinsi Jawa Barat dalam angka yang signifikan, verkurangnya kawasan hutan lindung (untuk konteks wilayah) dan terjadinya penggunaan lahan yang tidak sesuai rencana di kawasan perkotaan. Dalam skala kota dan kawasan, penyimpangan rencana tata ruang dapat dilihat dari pengembangan kawasan permukiman di kawasan Puncak.

Terkait dengan deviasi pemanfaatan ruang, Dinas Tata Ruang dan Lingkungan Hidup telah mencoba melihat besaran deviasi secara kuantitatif antara penggunaan lahan saat ini (eksisting) dengan beberapa produk rencana tata ruang yang ada. Dengan menggunakan "tools" GIS 
melalui suatu "software" Arc/Info, beberapa rencana tata ruang telah dilakukan análisis "overlay" terhadap penggunaan lahan eksisting, dengan diawali dengan pendefinisikan kriteria kesesuaian dari setiap polygon yang ada. Rencana tata ruang tersebut adalah sebagai berikut :

- RDTR Kawasan Pariwisata Puncak (Perda No. 3 Tahun 1988) dengan penggunaan lahan Tahun 1999.

- RTRW Kabupaten Bogor (Perda No. 17 Tahun 2000) dengan penggunaan lahan Tahun 1999.

- Keppres No. 114 Tahun 1999 dengan penggunaan lahan Tahun 1999.

Ketiga proses "overlay" tersebut, menghasilkan kesimpulan bahwa tingkat penyimpangan (deviasi) pemanfaatan ruang rata-rata diatas $20 \%$. Gambaran proses tersebut dapat dilihat pada gambar 2 dalam lampiran.

Berdasarkan gambaran kuantitatif tingkat penyimpangan (deviasi) pemanfaatan ruang yang terjadi tersebut (khususnya di Kabupaten Bogor), yang menjadi pertanyaan saat ini adalah faktor-faktor apa yang menjadi penyebab sekaligus pendorong terjadinya deviasi tersebut?. Untuk mengetahui faktorfaktor tersebut, harus dilihat dari tiga sisi, sebagai berikut :

- Dari sisi perencanaan ruang, yang menjadi issue "klasik" adalah rendahnya kualitas produk rencana tata ruang.

- Dari sisi pemanfaatan ruang, yang menjadi permasalahan adalah adanya "konflik kepentingan".

- Dari sisi pengendalian, yang menjadi permasalahan adalah rendahnya penegakan hukum yang terkait dengan pelanggaran pemanfaatan ruang.

Dari sisi perencanaan ruang, rendahnya kualitas rencana tata ruang dapat disebabkan oleh beberapa faktor berikut :

- Proses análisis yang merupakan salah satu tahapan dalam penyusunan rencana tata ruang, umumnya hanya didominasi oleh pertimbangan dari aspek fisik. Aspek sosial budaya serta perkembangan ekonomi local dan regional yang diprediksikan akan mempengaruhi perkembangan wilayah, kurang mendapat perhatian.

- Proses análisis yang umumnya dilakukan dengan mempergunakan data sekunder yang telah "out of date" maupun tingkat kebenaran data diragukan, sehingga hasil akhir menjadi semakin bias.

- Beberapa produk rencana tata ruang di Kabupaten Bogor (contoh : RDTR Kawasan Pariwisata Puncak), tidak mempunyai konsep perencanaan yang jelas, sehingga menimbulkan kesan "mengangkat" kondisi eksisting menjadi rencana tata ruang.

- Ketidakjelasan "benang merah" produk rencana tata ruang berdasarkan hirarki produk perencanaan, maupun produk rencana tata ruang antara dua daerah otonom yang berbatasan. Penjabaran dari RTRW Propinsi menjadi RTRW Kabupaten/Kota, dari RTRW Kabupaten/Kota menjadi RUTR Kota Kecamatan, dan dari RUTR Kota Kecamatan menjadi RDTR Kota Kecamatan, tidak sinkron.

- Faktor yang sangat "klasik", adalah kapasitas SDM penyusun renacana tata ruang yang rendah, keterbatasan anggaran/fasilitas pendukung, serta waktu penyusunan yang terbatas.

Dari sisi pemanfaatan, seringkali yang menjadi pokok persoalan adanya "konflik kepentingan". Konflik ini terjadi pada saat pemilik tanah merasa bahwa rencana tata ruang yang berlaku di atas tanah miliknya sudah tidak lagi memberikan nilai tambah yang maksimal apabila diusahakan sesuai dengan alokasi rencana tata ruang yang telah ditetapkan.

Dari sisi pengendalian, beberapa faktor penyebab deviasi pemanfaatan ruang sebagai berikut : 
- Kurangnya peran aktif masyarakat dalam monitoring pemanfaatan ruang. Dalam prakteknya, efektifitas pengendalian pemanfaatan ruang justru berada pada masyarakat.

- Mekanisme perijinan lokasi/IPPT yang longar, sehingga produk perijinan yang dikeluarkan seringkali menyimpang dari rencana tata ruang yang ada.

- Kurangnya penerapan perangkat insentif/disinsentif dalam rangka perwujudan rencana tata ruang. Sebagai ilustrasi apabila suatu wilayah ditetapkan sebagai kawasan pertanian, maka seoptimal mungkin berbagai program pembangunan yang mengarah kepada usaha pertanian dialokasikan pada kawasan tersebut.

Upaya yang perlu dilakukan untuk Kabupaten Bogor :

Seperti yang telah dijelaskan pada bagian terdahulu, bahwa untuk mengoptimalkan pemanfaatan ruang yang sejalan dengan rencana tata ruang, banyak faktor yang harus dipertimbangkan, baik yang menyangkut aspek perencanaan ruang, aspek pemanfaatan ruang, maupun aspek pengendalian pemanfaatan ruang.

Kaitan dengan mekanisme pemberian ijin lokasi yang mendukung tata ruang didaerah, secara garis besar, mekanisme pemberian ijin lokasi yang dilaksanakan telah memperhatikan rencana tata ruang yang ada. Untuk lebih mengoptimalkan hasil akhir pemberian ijin lokasi, tahapan penting perlu dilakukan adalah konsultasi publik. Pelibatan masyarakat, terutama masyarakat pemilik tanah awal, terutama untuk rencana kegiatan pemanfaatan ruang yang berskala besar dengan perkiraan dampak lingkungan dan ekonomi yang cukup luas, harus dimulai sejak awal.

Untuk lebih mengoptimalkan pemanfaatan ruang agar sesuai dengan rencana tata ruang yang ada, penggunaan teknologi GPS dan pengembangan Sistem Informasi Geografis sedini mungkin perlu dilakukan. Seiring dengan perkembangan teknologi satelit yang sangat pesat, dengan skala ketelitian yang semakin detail, maka proses identifikasi lapangan akan semakin akurat dan kebutuhan terhadap aplikasi teknologi GPS yang dikombinasikan dengan pengembangan "GIS" menjadi semakin tinggi.

\section{Analisis Pelanggaran Rencana Tata Ruang Wilayah Kawasan Puncak}

Guna menunjang analisis data yuridis penerapan pelaksanaan Tata Ruang di Kawasan Puncak, analisis data dilakukan dengan analisis superimpose mempergunakan peta-peta dan dilanjutkan dengan analisis tabulasi.

Apabila dua jenis peta dari suatu wilayah disuperimposekan, maka akan dapat dilihat adanya korelasi dari kedua jenis peta tersebut. Dengan mensuperimposekan peta-peta penggunaan tanah dan kemampuan tanah dengan peta Rencana Detail Tata Ruang Puncak, sehingga dapat diketahui seberapa jauh kesesuaian penggunaan tanah dan kemampuan tanah dengan RDTR.

Superimpose dilaksanakan dengan cara menumpang tindihkankan/overlay antara satu peta dengan peta lainnya, yang mempunyai skala yang sama dan harus transparan sehingga kedua peta tersebut dapat dilihat jenis luas masingmasing penggunaan di peta Penggunaan Tanah dan di peta Rencana Detail Tata Ruang yang dituangkan dalam bentuk angka.

Dalam kaitan ini penyusun menggunakan peta penggunaan tanah kecamatan Pacet, Cugenang dan Sukaresmi skala $1: 25.000$ dan peta kemampuan tanah (lereng) sajaka 1 : 25.000 disuperimposekan dengan Rencana Detail Tata Ruang Kawasan Puncak 1 : 25.000 yang diperoleh dari Kantor Bappeda Kabupaten Cianjur.

Dengan cara demikian dapat dilihat seberapa jauh kesesuaian antara peng- 
gunaan tanah, kemampuan tanah dan lingkungan hidup dalam penyusunan Rencana Detail Tata Ruang Kawasan Puncak.

Dari data superimpose antara peta Penggunaan Tanah dan peta Kemampuan Tanah (Lereng dan Ketinggian) dengan peta Rencana Detail Tata Ruang kawasan Puncak untuk memudahkan penyederhanaan dalam penampilan data maka penyusun melanjutkan dengan analisa tabulasi, yaitu data hasil superimpose dituangkan dalam bentuk tabel-tabel. Dengan cara demikian akan memudahkan untuk menganalisa lebih lanjut untuk ditarik kesimpulan.

Hasil superimpose dari masingmasing penggunaan tanah di Penggunaan Tanah dan arahan peruntukan-peruntukan penggunaan di Rencana Detail Tata Ruang kawasan Puncak dapat dilihat pada lampiran 1, 2 dan 3. Sedangkan untuk konversi penggunaan tanah sawah ke non pertanian dapat dilihat pada lampiran 4 dan 5 .

\section{Kawasan Lindung}

Dari hasil superimpose peta Penggunaan Tanah khususnya jenis penggunaan kehutanan dengan Rencana Detail Tata Ruang kawasan Puncak dapat dilihat pada tabel berikut :

TABEL 1

SUPERIMPOSE PENGGUNAAN TANAH DENGAN RDTR PUNCAK UNTUK ARAHAN KAWASAN LINDUNG

\begin{tabular}{|c|l|c|c|c|c|c|}
\hline No & Kecamatan & $\begin{array}{c}\text { Luas } \\
\text { Wilayah } \\
(\mathrm{Ha})\end{array}$ & $\begin{array}{c}\text { Penggunaan } \\
\text { Tanah } \\
(\mathrm{Ha})\end{array}$ & $\%$ & $\begin{array}{c}\text { RDTR } \\
(\mathrm{Ha})\end{array}$ & $\%$ \\
\hline 1. & Cugenang & $7.695,5$ & 1.502 & 22,17 & 1.626 & 19,89 \\
\hline 2. & Pacet & 10.503 & $3.688,5$ & 54,45 & 3.679 & 45,00 \\
\hline 3. & Sukaresmi & 9.676 & $1.583,5$ & 23,38 & $2.870,5$ & 35,11 \\
\hline \multicolumn{2}{|c|}{ Jumlah } & $\begin{array}{c}27.874, \\
5\end{array}$ & 6.774 & 100 & $8.175,5$ & 100 \\
\hline
\end{tabular}

Sumber: Analisa Data Sekunder 2007

Dari hasil perhitungan luas Penggunaan Tanah, jumlah kawasan hutan di wilayah Puncak yang harus dilindungi adalah 6.774 Ha sedangkan jumlah kawasan hutan yang diperuntukkan pada
Rencana Detail Tata Ruang kawasan Puncak sebesar 8. 175,5 Ha.

Melihat data tersebut diatas bahwa luas kawasan lindung dari ketiga kecamatan yang ada di kawasan puncak yaitu kecamatan Cugenang, kecamatan Pacet dan kecamatan Sukaresmi menunjukkan bahwa luas menurut penggunaan tanah sebesar 6.774 Ha, sedangkan luas pada Rencana Detail Tata Ruang kawasan Puncak 8.175,5 Ha, maka telah terjadi perbedaan luas sekitar 1.401,5 Ha, yang seharusnya masih dapat untuk dikembangkan menjadi kawasan budidaya. Terjadi perbedaan luas dikarenakan penggunaan tanah existing tidak dimanfaatkan sepenuhnya untuk menentukan arahan kawasan lindung dalam penyusunan RDTR kawasan Puncak. Maka dapat diketahui bahwa kesesuaian penggunaan tanah dalam menentukan arahan kawasan lindung pada penyusunan RDTR Puncak sebesar 79,3\%.

\section{Kawasan Penyangga}

Dari hasil superimpose Penggunaan Tanah dengan Rencana Detail Tata Ruang kawasan Puncak untuk arahan kawasan penyangga dapat dilihat pada tabel berikut :

TABEL 2

SUPERIMPOSE PENGGUNAAN TANAH DENGAN RDRT PUNCAK UNTUK ARAHAN KAWASAN PENYANGGA

\begin{tabular}{|c|l|c|c|c|c|c|}
\hline No. & Kecamatan & $\begin{array}{c}\text { Luas } \\
\text { Wilayah } \\
(\mathrm{Ha})\end{array}$ & $\begin{array}{c}\text { Penggunaan } \\
\text { Tanah (Ha) }\end{array}$ & $\%$ & RDTR & $\%$ \\
\hline 1. & Cugenang & $7.695,5$ & 694 & 32,42 & 674 & 23,20 \\
\hline 2. & Pacet & 10.503 & 1.021 & 50,65 & 1.929 & 69,18 \\
\hline 3. & Sukaresmi & 9.676 & 301 & 14,93 & 212,5 & 7,62 \\
\hline \multicolumn{2}{|l|}{ Jumlah } & $27.874,5$ & 2.016 & 100 & $2.78,5$ & 100 \\
\hline
\end{tabular}

Sumber : Analisa Data Sekunder 2007

Dari hasil perhitungan luas peta Penggunaan Tanah jumlah kawasan penyangga di wilayah Puncak yang harus dilindungi sebesar $2.016 \mathrm{Ha}$, sedangkan jumlah kawasan penyangga yang diperuntukkan pada Rencana Detail Tata 
Ruang kawasan Puncak adalah 2.788,5 Ha.

Berdasarkan data tersebut di atas bahwa kawasan penyangga yang termasuk dalam kawasan ini terdiri dari areal perkebunan teh, tanaman tahunan lainnya, hutan wisata dan hutan produksi lainnya.

Dalam kawasan penyangga masih dimungkinkan adanya pertanian dan permukiman pedesaan terbatas dengan memperhatikan sebesar-besarnya azas konservasi tanah, air, dan atau menunjang fungsi perkebunan.

Lokasi perkebunan teh terletak di wilayah kecamatan Pacet yang meliputi desa Batulawang, Sukanagalih, Sukaresmi, Cipendawa, Ciherang dan Ciputri.

Sedangkan di Kecamatan Cugenang meliputi desa Sukamulya, Padaluyu, Cirumput, Tegalega dan Sarampad.

Pada tabel 2 terlihat bahwa luas menurut penggunaan tanah existing untuk arahan kawasan penyangga seluas $2.016 \mathrm{Ha}$ sedangkan pada RDTR Puncak dialokasikan sebesar 2.788,5 Ha. Dari data tersebut menunjukkan bahwa ada 772,5 Ha lahan yang seharusnya menjadi kawasan penyangga masih dapat dikembangkan untuk kawasan budidaya. Terjadi perbedaan luas dikarenakan penggunaan tanah tidak dimanfaatkan sepenuhnya untuk menentukan arahan kawasan penyangga dalam penyusunan RDTR Puncak yang seharusnya ada persamaan luas berdasarkan hal tersebut dapat diketahui pula kesesuaian penggunaan tanah dalam menentukan kawasan penyangga sebesar $61,7 \%$.

\section{Kawasan Pertanian Lahan Kering}

Dari hasil superimpose Penggunaan Tanah dengan Rencana Detail Tata Ruang kawasan Puncak untuk arahan kawasan pertanian lahan kering dapat dilihat pada tabel berikut :
TABEL 3

SUPERIMPOSE PENGGUNAAN TANAH DENGAN RDTR UNTUK ARAHAN KAWASAN PERTANIAN LAHAN KERING

\begin{tabular}{|c|l|c|c|c|c|c|}
\hline No. & Kecamatan & $\begin{array}{c}\text { Luas } \\
\text { Wilayah } \\
(\mathrm{Ha})\end{array}$ & $\begin{array}{c}\text { Penggunaaan } \\
\text { Tanah } \\
(\mathrm{Ha})\end{array}$ & $\%$ & $\begin{array}{c}\text { RDTR } \\
(\mathrm{Ha})\end{array}$ & $\%$ \\
\hline 1. & Cugenang & $7.695,5$ & $2.561,5$ & 24,85 & $2.707,5$ & 26,76 \\
\hline 2. & Pacet & 10.503 & $2.952,5$ & 28,64 & 2.984 & 29,39 \\
\hline 3. & Sukaresmi & 9.676 & $4.795,5$ & 46,51 & 4.461 & 43,94 \\
\hline \multicolumn{2}{|l}{ Jumlah } & $27.874,5$ & $10.309,5$ & 100 & $10.152,5$ & 100 \\
\hline
\end{tabular}

Sumber : Analisa Data Sekunder 2007

Dari hasil perhitungan luas Penggunaan Tanah jumlah kawasan pertanian lahan kering di wilayah Puncak yang harus dilindungi adalah 10.309,5 Ha sedangkan kawasan pertanian lahan kering yang diperuntukkan pada Rencana Detail Tata Ruang kawasan Puncak adalah 10.152,5 Ha.

Bahwa berdasarkan data tersebut di atas kriteria dari pertanian lahan kering adalah kesesuaian lahan untuk kegiatan pertanian lahan kering meliputi : kebun campuran dan tegalan dimana di areal ini masih dimungkinkan secara terbatas adanya pemukiman pedesaan dan pariwisata serta saran penunjang lainnya dan masih dimungkinkan adanya perubahan dari pertanian yang satu ke pertanian yang lain atau jenis tanaman yang satu ke jenis tanaman yang lainnya atas dasar perhitungan ekonomis dan teknologi konservasi.

Lokasi pertanian lahan kering di kawasan Pacet meliputi desa Ciloto, Sukanagalih, Ciwalen, Sukaresmi, Sukamahi, Cibadak, Cikancana, Ciputri, Batu lawang, Cimacan, Ciherang, Sindangjaya, Sindanglaya, Palasari, Sukatani, dan Cipendawa.

Kesesuaian arahan penggunaan tanah dalam penyusunan RDTR kawasan Puncak 10.309,5 Ha, maka terjadi perbedaan sebesar $157 \mathrm{Ha}$. Terjadi perbedaan luas dikarenakan penggunaan tanah existing tidak dimanfaatkan sepenuhnya untuk menentukan arahan kawasan pertanian lahan kering. Atas dasar tersebut dapat diketahui bahwa dalam pencadangan untuk kawasan lahan 
kering menggunakan kawasan lahan basah sebesar 157 Ha. Berarti pula ada konversi lahan basah menjadi lahan kering sehingga mengakibatkan pembangunan yang berlokasi pada penggunaan lahan sawah, tapi menurut RDTR Puncak lahan kering. Dengan demikian kesesuaian arahan penggunaan tanah dalam menentukan arahan pertanian lahan kering sebesar 98,5\%.

\section{Kawasan Pertanian Lahan Basah}

Dari hasil superimpose Penggunaan Tanah dengan Rencana Detail Tata Ruang kawasan Puncak untuk arahan kawasan pertanian lahan basah dapata dilihat pada tabel berikut :

TABEL 4

SUPERIMPOSE PENGGUNAAN TANAH DENGAN RDTR UNTUK ARAHAN KAWASAN PERTANIAN LAHAN BASAH

\begin{tabular}{|c|l|c|c|c|c|c|}
\hline No. & Kecamatan & $\begin{array}{c}\text { Luas } \\
\text { Wilayah } \\
(\mathrm{Ha})\end{array}$ & $\begin{array}{c}\text { Peng. } \\
\text { Tanah } \\
\text { Sawah } \\
(\mathrm{Ha})\end{array}$ & $\%$ & $\begin{array}{c}\text { RDTR } \\
(\mathrm{Ha})\end{array}$ & $\%$ \\
\hline 1. & Cugenang & $7.695,5$ & 2.368 & 35,04 & 2.266 & 44,06 \\
\hline 2. & Pacet & 10.503 & $1.861,5$ & 27,55 & 933,5 & 18,15 \\
\hline 3. & Sukaresmi & 9.676 & 2.528 & 37,41 & 1.944 & 37,39 \\
\hline \multicolumn{2}{|l}{ Jumlah } & $27.874,5$ & $6.757,5$ & 100 & $5.143,5$ & 100 \\
\hline
\end{tabular}

Sumber : Analisa Data Sekunder 2007

Dari hasil perhitungan luas Penggunaan Tanah jumlah kawasan pertanian lahan basah (sawah) di wilayah Puncak yang harus dilindungi adalah $6.757,5 \mathrm{Ha}$ sedangkan jumlah kawasan pertanian lahan basah yang diperuntukkan pada Rencana Detail Tata Ruang kawasan Puncak sebesar 5.143,5 Ha.

Berdasarkan data tersebut di atas, ruang yang diperuntukkan bagi budidaya tanaman padi sawah, perikanan dan budidaya lahan lainnya baik secara bergilir musim maupun terus-menerus sepanjang tahun. Adapun kriteria kesesuaian lahan sesuai untuk tanaman padi sawah menurut Departemen Pertanian telah ada dibangun sarana pengairan teknis ataupun setengah teknis, mempertahankan sawah yang telah ada terutama sawah yang telah ada terutama sawah irigasi teknis.

Adapun pengaturan dalam kawasan pertanian lahan basah perlu pemeliharaan sumber-sumber air bagi kelangsungan irigasi.

Dalam peruntukan tanaman pangan lahan basah yang masih mempergunakan sistem irigasi sederhana atau semi-teknis masih diperkenankan adanya beberapa hal :

- Rotasi tanaman atau tumpang sari

- Mengganti budidaya atas dasar pertimbangan ekonomis yang lebih tinggi.

- Building Coverage Ratio (BCR) bangunan perkavling maksimal 5\% pada sawah tadah hujan.

Areal pertanian lahan basah terletak di wilayah kecamatan Pacet yang meliputi desa Batulawang, Cibadak, Sukanagalih, Cibodas, Ciwalen, Kawungluwuk, Cikanyere, Sukamahi, Sukaresmi, Cikancana, Ciputri, Ciherang, Cipendawa, Sindangjaya dan Palasari.

Sedangkan di kecamatan Cugenang meliputi desa Nyalindung, Cibeureum, Galudra, Mangunkerta, Sarampad, Talaga, Cirumput, Sukajaya, Cibulakan, Benjot, Gasol, Sukamanah, Cijedil dan Mangunkerta.

Untuk mengetahui kesesuaian penggunaan tanah dalam menentukan arahan peruntuk pada RDTR Puncak sebagai berikut.

Arahan penggunaan tanah 6.757,5 $\mathrm{Ha}$ sedangkan arahan pada RDTR Puncak 5.143,5 Ha ini membuktikan bahwa ada lahan pertanian sawah yang dikonversikan menjadi non sawah seluas $1.614 \mathrm{Ha}$. Terjadi perbedaan luas dikarenakan penggunaan tanah existing tidak dimanfaatkan sepenuhnya untuk menentukan arahan kawasan pertanian lahan basah.

Padahal untuk menghasilkan penggunaan tanah yang efektif dan efisien maka letak tiap kegiatan pembangunan harus diarahkan sesuai dengan ruang/ 
lokasi yang telah dipilih sesuai dengan kemampuan tanahnya.

Dari data di atas menunjukkan bahwa penggunaan tanah dimanfaatkan untuk menentukan kawasan lahan basah hanya sebesar $76,1 \%$.

Dengan demikian ada $1.641 \mathrm{Ha}$ sawah yang dikonversikan menjadi lahan pertanian non sawah (perumahan). Hal tersebut terbukti dengan pelaksanaan pembangunan perumahan oleh beberapa developer di kawasan Puncak, penggunaan tanah existing adalah lahan sawah seperti terlihat dalam lampiran : 4 dan lampiran 5.

\section{Kawasan Budidaya Non Pertanian}

Dari hasil superimpose Penggunaan Tanah dengan Rencana Detail Tata Ruang kawasan Puncak untuk arahan kawasan budidaya non pertanian dapat dilihat pada tabel berikut :

TABEL 5

SUPERIMPOSE PENGGUNAAN TANAH DENGAN RDTR PUNCAK UNTUK ARAHAN KAWASAN BUDIDAYA NON PERTANIAN

\begin{tabular}{|c|l|c|c|c|c|c|}
\hline No. & Kecamatan & $\begin{array}{c}\text { Luas } \\
\text { Wilayah } \\
\text { (Ha) }\end{array}$ & $\begin{array}{c}\text { Peng. } \\
\text { Tanah } \\
\text { Sawah } \\
\text { (Ha) }\end{array}$ & $\%$ & $\begin{array}{c}\text { RDTR } \\
\text { (Ha) }\end{array}$ & $\%$ \\
\hline 1. & Cugenang & $7.695,5$ & 570 & 28,25 & 449 & 31,84 \\
\hline 2. & Pacet & 10.503 & 979,5 & 48,55 & 977 & 54,83 \\
\hline 3. & Sukaresmi & 9.676 & 498 & 23,20 & 188 & 13,33 \\
\hline \multicolumn{2}{r}{ Jumlah } & $27.874,5$ & $2.017,5$ & 100 & 1.614 & 100 \\
\hline
\end{tabular}

Sumber : Analisa Data Sekunder 2007

Dari hasil perhitungan luas Penggunaan Tanah jumlah kawasan budidaya non pertanian di wilayah Puncak yang harus dilindungi adalah 2.017,5 $\mathrm{Ha}$ sedangkan jumlah kawasan budidaya non pertanian yang diperuntukkan pada Rencana Detail Tata Ruang kawasan Puncak adalah 1.614 Ha.

Pada kawasan ini termasuk pula kawasan-kawasan seperti :

1. Permukiman Perkotaan

Ruang yang diperuntukkan bagi pemukiman penduduk perkotaan dengan kepadatan penduduk relatif tinggi (45-225 jiwa/hektar) termasuk di dalamnya sarana dan prasarana sosial ekonomi bagi penduduknya, dominasi kegiatan merupakan kegiatan non pertanian.

2. Permukiman Pedesaan

Ruang yang diperuntukkan bagi pengelompokan pemukiman/perumahan penduduk yang terikat dengan tata lingkungan pedesaan, dengan dominasi kegiatan usaha di bidang pertanian didasarkan kepada kriteria pengelompokan lokasi pemukiman kpedesaan yang telah ada, menghindari sawah irigasi, memperhatikan kebutuhan perumahan penduduk pedesaan di masa mendatang kebutuhan penduduk felatif rendah ratarata 25 jiwa/hektar.

3. Pariwisata dan Rekreasi

Ruang yang merupakan tujuan manusia untuk rekreasi, istirahat atau kegiatan yang menunjang atau jasa pelayanan bagi para pengunjung, ruang ini dapat berupa keadaan alam atau areal kunjungan yang mempunyai sarana dan prasarana pokok kepariwisataan.

Dalam penentuan kawasan budidaya non pertanian terlihat bahwa dalam penggunaan tanah seluas $2.017,5 \mathrm{Ha}$ sedangkan pada RDTR Puncak 1.614,5 Ha. Terjadi perbedaan luas dikarenakan penggunaan tanah tidak dimanfaatkan sepenuhnya untuk menentukan kawasan budidaya non pertanian. Sehingga terjadi perbedaan sebesar 403 Ha yang seharusnya dicadangkan untuk kawasan permukiman dan pariwisata. Dengan demikian kesesuaian penggunaan tanah dlam penentuan arahan peruntukan budidaya non pertanian sebesar $80 \%$.

Untuk memperjelas kesesuaian penggunaan tanah dan Rencana Detail Tata Ruang kawasan Puncak (Perda No. 3 Tahun 1988) dapat dituangkan dalam bentuk tabel sebagai berikut : 
TABEL 6

KESESUAIAN PENGGUNAAN TANAH DENGAN RDTR PUNCAK

\begin{tabular}{|c|l|c|}
\hline No. & $\begin{array}{l}\text { Arahan Peruntukan pada } \\
\text { RDTR Puncak }\end{array}$ & $\begin{array}{c}\text { Kesesuaian Penggunaan Tanah } \\
\text { dengan RDTR Puncak (\%) }\end{array}$ \\
\hline 1. & Kawasan Lindung & 79,3 \\
\hline 2. & Kawasan penyangga & 61,7 \\
\hline 3. & $\begin{array}{l}\text { Kawasan pertanian lahan } \\
\text { kering }\end{array}$ & 98,5 \\
\hline 4. & Lahan basah & 76,1 \\
\hline 5. & Kawasan non budidaya & 80,0 \\
\hline \multicolumn{2}{|c|}{ Jumlah rata-rata } & 79,1 \\
\hline
\end{tabular}

Sumber : Analisa Data Sekunder 2007

Dari data perhitungan luas pada Penggunaan Tanah untuk kawasan yang tidak boleh dikembangkan (kawasan non budidaya) seluas $10.500 \mathrm{Ha}$ sedangkan jumlah kawasan non budidaya pada Rencana Detail Tata Ruang kawasan Puncak seluas 10.233 Ha.

Begitu pula untuk kawasan budidaya pada Penggunaan Tanah seluas $17.374,5$ Ha sedangkan jumlah kawasan budidaya pada Rencana Detail Tata Ruang kawasan Puncak adalah 17.641,5 Ha.

Dengan demikian ada sekitar $267 \mathrm{Ha}$ yang tidak dicadangkan untuk non budidaya.

Dari data hasil superimpose antara Penggunaan Tanah dengan Rencana Detail Tata Ruang kawasan Puncak menunjukkan masih adanya penyimpangan dari kenyataan yang ada di lapangan, menurut Penggunaan Tanah dengan arahan peruntukan pada Rencana Detail Tata Ruang kawasan Puncak.

Hal ini disebabkan karena antara Penggunaan Tanah dengan Rencana Detail Tata Ruang kawasan Puncak terdapat perbedaan luas peruntukan ruang seperti pada tabel 7 , terjadi hal demikian karena tidak ada kesesuaian antara Penggunaan Tanah dengan Rencana Detail Tata Ruang kawasan Puncak.

Untuk memperjelas dari uraianuraian kesesuaian Penggunaan Tanah dalam penyusunan Rencana Detail Tata Ruang kawasan Puncak, dituangkan dalam bentuk tabel berikut :

\begin{tabular}{|c|c|c|c|c|c|c|}
\hline \multirow[b]{3}{*}{ No } & \multicolumn{5}{|c|}{$\begin{array}{c}\text { TABEL } 7 \\
\text { PERBEDAAN LUAS PERUNTUKAN KAWASAN PUNCAK } \\
\text { BERDASARKAN PENGGUNAAN TANAH DAN RDTR }\end{array}$} & \multirow[b]{3}{*}{$\begin{array}{l}\text { Perbedaan } \\
\text { Luas (Ha) }\end{array}$} \\
\hline & \multirow[b]{2}{*}{ Peruntukan Ruang } & \multicolumn{4}{|c|}{ Luas (Ha) } & \\
\hline & & $\begin{array}{c}\text { Penggunaan } \\
\text { Tanah }\end{array}$ & $\%$ & RDTR & $\%$ & \\
\hline 1. & Kawasan Lindung & 6.774 & 24,30 & $8.175,5$ & 29,33 & $-1401,5$ \\
\hline 2. & Kawasan Penyangga & 2.016 & 7,23 & $2.788,5$ & 10,00 & $-772,5$ \\
\hline 3. & $\begin{array}{l}\text { Kawasan Pertanian } \\
\text { Lahan Kering }\end{array}$ & $10.309,5$ & 36,99 & $10.152,5$ & 36,43 & +157 \\
\hline 4. & $\begin{array}{l}\text { Kawasan Pertanian } \\
\text { Lahan Basah }\end{array}$ & $6.757,5$ & 24,24 & $5.143,5$ & 18,45 & +1614 \\
\hline 5. & $\begin{array}{lr}\text { Kawasan } & \text { Budidaya } \\
\text { Non } & \text { Pertanian } \\
\text { (Pemukiman } & \text { dan } \\
\text { Pariwisata) } & \\
\end{array}$ & $2.017,5$ & 7,24 & $1.614,5$ & 5,79 & +403 \\
\hline & Jumlah & $27.874,5$ & 100 & $27.874,5$ & 100 & \\
\hline
\end{tabular}

Sumber: Analisa Data Sekunder 2007

Dari tabel 7 dapat dijelaskan bahwa yang hampir mendekati kesesuaian optimal adalah dalam peruntuk kawasan pertanian lahan kering yaitu menurut Penggunaan Tanah seluas 10.309,5 Ha sedangkan menurut Rencana Detail Tata Ruang kawasan Puncak seluas 10.152,5 Ha berarti ada perbedaan sekitar $157 \mathrm{Ha}$.

Sedangkan untuk kawasan penyangga, kawasan lindung dan kawasan pertanian basah serta kawasan budidaya non pertanian (permukiman dan pariwisata) masih menunjukkan adanya kurang kesesuaian antara luas Penggunaan Tanah dengan luas Rencana Detail Tata Ruang kawasan Puncak.

\section{PENUTUP}

\section{Kesimpulan}

Dengan memperhatikan pokok permasalahan dan berdasarkan data-data yang diperoleh dari pelaksanaan penelitian, maka dapat ditarik kesimpulan akhir sebagai berikut :

1. Bahwa Rencana Tata Ruang Wilayah (RTRW) yang telah di tetapkan PEMDA Jawa Barat ternyata "belum sepenuhnya" dapat dilaksanakan, hal ini di dasarkan pada penjelasan yang diperoleh dari pihak PEMDA Jawa Barat bahwa RTRW yang ditetapkan baru terlaksana sekitar $80 \%$ sedang- 
kan sisanya (20\%) masih dalam upaya realisasinya. Adapun yang belum terlaksana antara lain pembayaran jalan provinsi dan akses jalan lain baik yang arahnya menuju jalan tol maupun arah keluar setelah melalui jalan tol, sehingga kemacetan lalu lintas belum teratasi. Di samping itu juga realisasi Penataan Kawasan Lindung dan Ruang Terbuka Hijau (RTH) yang realisasinya masih agak jauh dari harapan, mengingat luas dan banyaknya wilayah kawasan lindung Jawa Barat sedangkan dana yang tersedia sangat terbatas. Berikut ini akan di kemukakan beberapa kawasan lindung di Jawa Barat yang pengelolaannya masih jauh dari harapan bahkan terdapat pelanggaran pemanfaatannya kawasan lindung termasuk adalah :

a. Suaka Marga Satwa Cikepuk

b. Suaka Marga Satwa Gunung Sawah

c. Cagar Alam Gunung Tangkuban Perahu

d. Cagar Alam Leuweung Sancang

e. Cagar Alam Gunung Tilu

f. Cagar Alam Gunung Papandaran

g. Cagar Alam Gunung Burangrang

h. Cagar Alam Kawah Kamojang

i. Cagar Alam Laut Leuweung Sancang

j. Cagar Alam Gunung Simpang

k. Taman Nasional Gunung Halimun

1. Taman Nasional Gunung Salak

m.Taman Nasional Gunung Gede Pangrongo

n. Taman Nasional Gunung Ceremai

o. Taman Wisata Alam Gunung Tampomas

p. Taman Wisata Alam Laut Cijulang

q. Taman Buru Gunung Masigit Kareumbi

Tujuh belas kawasan lindung di Jawa Barat itu pada kenyataannya pengelolaan daerah tersebut masih jauh dari harapan dan diperkirakan baru sekitar 60\% dari target yang akan dicapai.

Kawasan lindung adalah wilayah yang ditetapkan dengan fungsi utama melindungi kelestarian lingkungan hidup yang mencakup sumber daya alam dan sumber daya buatan (UU No. 26 Tahun 2007 Pasal 1 butir 21 jo PP. 26 Tahun 2008 Pasal 1 butir 9). Dalam areal kawasan lindung harus di wujudkan "Pelestarian lingkungan" disini tidak ada pembangunan besarbesaran seperti di kota-kota besar tetapi harus di kondisikan sebagai wilayah yang terawat dan terpelihara dengan baik. Untuk wilayah Jawa Barat pengelolaan kawasan lindung (terutama perawatan, perlindungan dan pemeliharaan) masih agak jauh dari rencana yang telah ditetapkan.

2. Terdapat beberapa pelangaran terhadap RTRW yang telah di tetapkan PEMDA Propinvi Jawa Barat maupun PEMDA Kabupaten setempat. Tingkat atau jenis pelanggaran dan prosentasenya sangat bervariasi mengingat wilayah provinsi Jawa Barat cukup luas. Pelanggaran yang paling banyak adalah tentang :

a. Pemanfaatan RTH yang tidak sesuai dengan fungsi RTH itu sendiri.

b. Alih guna tanah dikawasan lindung (yang seharusnya tidak di perbolehkan).

c. Pemanfaatan tanah di daerah resapan air tidak sesuai dengan RTRW setempat.

3. Upaya-upaya Pemerintah Daerah Jawa Barat dalam mengatasi pelanggaran RTRW antara lain:

a. Memperketat penertiban izin-izin mendirikan bangunan terutama di daerah yang diperkirakan akan menimbulkan pengurangan daerah resapan air.

b. Mensosialisasikan RTRW yang telah ditetapkan Pemda. 
c. Melakukan pengawasan yang lebih ketat dalam rangka penerapan RTRW.

d. Melakukan pembinaan secara aktif terhadap aparat Pemda terkait penerapan RTRW.

e. Mengadakan penyuluhan hukum berkaitan dengan penerapan RTRW.

\section{Saran}

Berdasarkan hasil penelitian yang telah dilaksanakan, kiranya dapat disampaikan beberapa saran sebagai berikut :

1. Dalam rangka mencegah dan/atau mengurangi pelanggaran terhadap RTRW yang telah ditetapkan, perlu segera ditetapkan ketentuan tentang Pemberian Insentif dan diseisentif tentang Penataan Ruang.

2. PEMDA hendaknya konsekwen dalam penerapan RTRW yang telah ditetapkan.

3. Hendaknya pengenaan sanksi terhadap pelaku pelangaran penataan ruang (baik pejabat Pemda maupun anggota masyarakat) dilaksanakan dengan tegas sesuai UUPR yang meliputi sanksi Administratif Perdata maupun Pidana.

\section{DAFTAR PUSTAKA}

Adhie Brahmana dan Hasan Basri Nata Menggala, Reformasi Pertanahan Pemberdayaan Hak-Hak Atas Tanah Ditinjau Dari Aspek Hukum, Sosial, Politik, Ekonomi, Hankam, Teknis, Agama dan Budaya, Sekolah Tinggi Pertanahan Nasional, Penerbit mandar Maju Bandung, 2002.

A.D. Belinfante dan Burhanoeddin Soetan Batuah, Pokok-Pokok Hukum Tata Usaha Negara, Bandung : Bina Cipta, 1983.
Al Araf Awan Puryadi, Perebutan Kuasa Tanah, Yogyakarta : Lappera Pustaka Utama, 2002.

Amiruddin, H. Zainal Asiki, Pengantar Metode Penelitian Hukum, Jakarta : Raja Grafindo Persada, 2003.

Anthony Giddens, Jalan Ketiga : Pembaharuan Demokrasi Sosial, terjemahan Ketut Arya Madardika, cet.2, Jakarta : Gramedia Pustaka Umum, 2000.

Arie Sukanti Hutagalung, Diktat Tata Guna Tanah dan Landreform, Jakarta : UI .

Badan Pertanahan Nasional, Pertanahan Indonesia, Suatu Retrospeksi. Ekspose Badan Pertanahan Nasional Dihadapan Ibu Megawati Sukarnoputri, Jakarta, 2001.

Rencana Strategis Bidang Pertanahan Tahun 2001-2004.

Kewenangan Pemerintah di Bidang Pertanahan Dalam Rangka Otonomi Daerah, Suatu Keyakinan, Jakarta, 2001.

Organisasi dan Tata Kerja Badan Pertanahan Nasional, Keputusan KBPN No. 6 Tahun 2001, Jakarta, 2001.

Implementasi TAP MPR No. $I X / M P R / 2001 \quad$ tentang Pembaharuan Agraria dan Pengelolaan Sumber Daya Alam, Suatu Perspektif, Jakarta, 2002.

Hasil Rapat Kerja Badan Pertanahan Nasional Tahun 2002, Buku I, Jakarta 2002 
Badan Pusat Statistik Kabupaten Cianjur, Kabupaten Cianjur Dalam Angka 2004/2005.

Bagir Mana dan Kuntana Magnar, Beberapa Masalah Hukum Tata Negara Indonesia, Bandung : Alumni, 1993.

Bambang Sunggono, Metodologi Penelitian Hukum, Jakarta : Raja Grafindo Persada, 1996.

B.Hestu.C. Handoyo, Aspek-Aspek Hukum Administrasi Negara dalam Penataan Ruang, Yogyakarta : Unika Atmajaya, 1995.

Boedi Harsono, Hukum Agraria Indonesia, Himpunan Peraturan-Peraturan Hukum Tanah, Edisi Revisi 2007, Penerbit Djambatan.

Hukum Agraria Indonesia, Sejarah Pembentukan Undang-Undang Pokok Agraria, Isi dan Pelaksanaannya, Jilid 1 Hukum Tanah Nasional, Edisi Revisi 2005, Penerbit Djambatan.

Bushar Muhammad, Azas-Azas Hukum Adat : Suatu Pengantar, cet.6, Jakarta : Pradnya Paramita, 1986.

C.F.G. Sunaryati Hartono, Hukum Ekonomi Pembangunan Indonesia, Bandung : Bina Cipta.

Azas Umum Pemerintahan Yang Baik Sebagai Tolok Ukur Good Governance di Indonesia, Seminar Rancangan Undang-Undang Administrasi Pemerintahan, Makasar : 1 Juni 2005.
David.W.Pearce dan R. Kerry Turner, Economics of Natural Resources and The Environment, New York : Harvester Wheatsheaf, 1990.

Departemen Dalam Negeri, Prosedur Perencanaan Tata Guna Tanah, Pokok-Pokok Penggarisan Tata Guna Tanah di Daerah Pedesaan, Pokok-Pokok Penggarisan Tata Guna tanah di Daerah Perkotaan, Jakarta, 1975.

Atlas Penggunaan Tanah Republik Indonesia, Direktorat Jenderal Agraria, Jakrta 1984.

Direktorat Tata Guna Tanah, Pokok Pokok Tata Guna Tanah (Land Use) Dalam Perencanaan Tata Ruang, Publikasi No. 32, Jakarta, 1973.

Direktorat Jenderal Agraria 1997, Penggunaan Tanah (Land Use), Pulikasi No. 75.

Edmondson and Loates, Land Use Policy, volume 2 no. 1 Westbury House, Guidford, United Kingdom, 1985.

Efendi, Himpunan Beberapa Peraturan Pertanahan Bidang Penatagunaan Tanah, Direktorat Hukum Pertanahan Nasional, Jakarta 2005.

Eko Budihardjo dan Djoko Sujarto, Kota Berkelanjutan, Bandung : Alumni, 1999

Tata Ruang Perkotaan, Bandung : Alumni, 2005. 
H. Wijono, Mekanisme Penatagunaan Tanah Dalam Pengelolaan Pertanahan di Pusat, Provinsi dan Kabupaten Kota, Loka Karya Kewenangan Pemerintah Dalam Rangka Otonomi Daerah, Land Management and Policy Development Program, Hotel Hilton, Jakarta, 2002.

Indroharto, Usaha Memahami UndangUndang tentang Peradilan Tata Usaha Negara, Buku 1, Jakarta : Pustaka Sinar harapan, 1993.

Jayadinata, Tata Guna Tanah Dalam Perencanaan Pedesaan, Perkotaan dan Wilayah, Bandung: Penerbit ITB, 1992.

Keputusan Presiden RI No. 79 Tahun 1985.

Koesnadi Hardjasoemantri, Hukum Tata Lingkungan, Edisi Ketujuh, cet.Ketujuh belas, Yogyakarta : Gadjah Mada University Press.

Lutfi Nasoetion, Pertanahan Indonesia, Masalah dan Harapan, Makalah Disampaikan Pada Pembahasan Substansi Materi Pembaharuan Agraria, Panitia Ad Hoc II Badan Pekerja MPR RI, Gedung Nusantara IV MPR RI, Jakarta, 2001.

M. Daud Silalahi, Hukum Lingkungan Dalam Sistem Penegakan Hukum Lingkungan Indonesia, Bandung : P.T. Alumni, 2001.

M. Nad Darga Talkulputra, Urgensi Penatagunaan tanah sebagai Pelaksanaan Penataan Ruang, Dalam Kebijakan Tata Ruang Nasional dan Aspek Pertanahan, cet.1, Penerbit CIDES, 1996.
M. Sigalingging, Analisis Penggunaan Tanah, Direktorat Penatagunaan Tanah, Badan Pertanahan Nasional, Jakarta, 2002.

Neraca Penggunaan Tanah Spasial Di Indonesia, Temu Karya Nasional Neraca Sumber Daya Alam Spasial, Hotel Kaisar, Jakarta, 2002

M. Sumardjono, Kebijakan Pertanahan antara Regulasi dan Implementasi, Jakarta : Penerbit Buku Kompas, 2002.

Noer Fauzi dan Khisna Ghimire, Reformasi Agraria Jalan Penghidupan dan Kemakmuran Rakyat, Yogyakarta : Lappera Pustaka Utama, 2001.

Peraturan Pemerintah Nomor 16 Tahun 2004 tentang Penatagunaan Tanah.

Phillipus M.Hardjon dkk, Pengantar Hukum Administrasi Indonesia, Yogyakarta : Gajahmada University Press, 1994.

Prajudi Atmosudirdjo, Hukum Administrasi Negara, Jakarta : Ghalia Indonesia, 1984.

Prins. Dalam M. Nata Saputra, Hukum Administrasi Negara, Jakarta : Rajawali, 1988.

Ridwan, H.R, Hukum Administrasi Negara, Yogyakarta : UII-Press, 2003.

R. Roestandi, Hukum agraria Indonesia Dalam Teori dan Praktek, cet. Kedua, Bandung : N.V. Masa Baru, 1962. 
Ronny Hanitijo Soemitro, Metodologi Penelitian Hukum, Jakarta : Ghalia Indonesia, 1982.

R. Soepomo, Sistem Hukum di Indonesia Sebelum Perang Dunia II, cet.4, Jakarta : Pradnya Paramita, 1972.

S.B. Silalahi, Penggunaan Tanah dan Faktor-Faktor yang Mempengaruhi Daerah Pedesaan di Propinsi Sumatera Utara, Publikasi No. 215, Direktorat Tata Guna Tanah, Departemen dalam Negeri, Jakarta, 1982.

Soeniarto, Undang-Undang Dasar 1945 Sebagai Hukum Negara Yang Tertinggi.

Soerjono Soekamto, Sri Mamudji, Penelitian Hukum Normatif, Suatu Tinjauan Singkat, Jakarta : Rajawali, 1985.

Pengantar Penelitian Hukum, cet.3, Jakarta : UI Press, 1986.

Steven Lukes, Emile Durkheim, His Life and Work : A Historical and Crotical study, Harmonds Worth : Penguin Book, 1973.

Sudargo Gautama, Pengertian tentang Negara Hukum, Bandung : Alumni, 1983.

Sudikno Mertokusumo and Pitlo, Bab-Bab tentang Penemuan Hukum, Bandung : Citra Aditya Bakti, 1993.

Syachran Basah, Tiga tulisan tentang Hukum, Bandung ; Armico, 1986.
Sistem Perizinan Sebagai Instrument Pengendali Lingkungan, Dalam butir-Butir gagasan tentang Penyelenggaraan Hukum dan Pemerintahan Yang Layak.

-------- Sebuah Tanda Mata 70 Tahun Ateng Syafrudin, Bandung : Citra Aditya Bahakti, 1996.

TIM, Hasil Penelitian tentang penyusunan Materi Teknis Pengaturan Pelaksanaan Hak Warga Negara dalam Pemanfaatan Ruang, Kerjasama Direktorat Tata Kota dan Tata Bangunan Direktorat Jenderal Cipta Karya, Departemen Pekerjaan Umum dan Fakultas Hukum Universitas Padjajaran, Bandung 7 September 1992.

Utrecht E dan Moh Saleh Djindang

Undang-Undang Nomor 5 Tahun 1960 tentang Peraturan Dasar Pokok Pokok Agraria

Undang-Undang Nomor 5 Tahun 1986 tentang Peradilan Tata Usaha Negara.

Undang-Undang Nomor 26 Tahun 2007 tentang Penataan Ruang.

Undang-Undang Nomor 23 Tahun 1997 tentang Pengelolaan Lingkungan Hidup.

Undang-Undang Nomor 41 Tahun 1999 tentang Kehutanan 